
\title{
POECT OF CERTAIN AGRICULTURAL PRACTCES ON POPULATION DENSITY OF THE RED STRIPED SOFT SCALE, PULVINARIA TENUIVALVATA (NEWSTEAD) (HOMOPTERA: COCCIDAE).
}

\author{
Ramadan A.K. Salama ${ }^{1}$, El-Metwally F. El.Metwally ${ }^{2}$ and Hosam A. \\ Saleh $^{2}$ \\ 1- Department of Economic Entomology and Pesticides, Faculty of \\ Agriculture ,Cairo University, Giza, Egypt. \\ 2- Plant Protection Research Institute, Agriculture Research Center, \\ Dokki, Egypt.
}

\section{ABSTRACT:}

The present investigation was carried out to study the efficiencies of agricultural practices i.e. rowing space, fertilization, irrigation system, ratoons, varieties and host range on the population density of red striped soft scale, Pulvinaria tenuivalvata (Newstead) at Nagada, Armant and Luxor City, Qena governorate during two successive seasons 2002 and 2003 where the results clearly showed that planting sugarcane on 7 rows space, using the recommended nitrogen fertilizer 200 units with $100 \mathrm{~kg}$ potassium per feddan, using modern irrigation, and choosing PH 8013 variety were considered the proper agricultural practices which decreased the population of $P$. tenuivalvata, and resulted in the increasing of both sugarcane yield and juice.

Key words: Soft scale, Pulvinaria tenuivalvata, Ecology, Sugarcane, Agricultural practices.

\section{INTRODUCTION}

Sugarcane (Saccharum officinarum L.) is one of the most important sources of sugar production that should be grown in large scale in tropical and sub tropical countries. In Egypt, sugarcane is the second most important economic crop. Numerous and serious pests invade sugarcane plants and cause a lot of damage which affect sugarcane yield and juice quality, (Willams, 1970; Mohalkar et al., 1973 and Campos, 1997) the main sucking insect the red striped soft scale, Pulvinaria tenuivalvata (Newstead), are considered recently the Key pests of sugarcane production in Egypt. (Ali et al., 2000 Watson \& Foldi, 2001 and Shalaby, 2002).

The chemical control of the insect pests had caused environmental pollution and serious harmful side effects to humans, domestic animals and natural enemies. The efficiency of agriculture practices on the population density could be taken into consideration as a mean of control measure of the major sugarcane insect pest (Raghunath, 1983; Rae \& Jones, 1992; Parsana et al., 1994; Ali et al., 2000; Besheit et al., 2002 and Shalaby 2002). Therefore, the current investigation was planned to study the effect of certain agriculture practices such as planting spaces, level of fertilization, irrigation system, plant crop \& ratoon plant sugarcane varieties and host range on the population dynamics of Pulvinaria tenuivalvata 
Ramadan A.K. Salama, et al.

\section{MATERIAL AND METHODS}

An area about one and half feddan were cultivated by C9/54 sugarcane variety at Nagada, Armant and Luxor City, Qena governorate in 30 of March in both $1^{\text {st }}$ and $2^{\text {nd }}$ seasons (2002 and 2003) Split-split plot and randomized complete block designs with three replicates were used. Samples of 90 leaves of 10 plants were inspected in the field at three different levels of plant height (i.e. upper, middle and lower) after 90 days from planting and continued at 15 days intervals during the period experiment. The number of nymphs and adults found on both surfaces of each leaf was counted and recorded to express the population size of this insect pest.

\section{Rowing space and fertilization.}

This experiment carried out as plant crop and its first ratoon during 2002 and 2003 seasons, respectively aimed to study the effect of rowing space (7 recommended, 9 and 11 rows) and levels of nitrogen fertilizer (150, 200 recommended and 250 units/fed.) under two levels of Potassium fertilizer (without and $100 \mathrm{~kg} / \mathrm{fed}$.) on population fluctuation of P.tenuivalvata and relationship of them on sugarcane yield and juice production quality. The rowing space were arranged in the sub-plots and level of Nitrogen fertilizer were distributed in sub-sub plots.

The area of each sub plot was $70 \mathrm{~m}^{2}(7 \times 10 \mathrm{~m}$.) represented $1 / 60$ fed. Nitrogen fertilizer was added, as Urea (46.5\%) and divided into two equal doses, the first application at full germination stage, after one month from planting, the second dose was added after one month later. Potassium fertilizer was added as Potassium sulphate (48\%) was applied with the second dose of Nitrogen. The phosphorus fertilizer was added as one dose during the land preparation. Meanwhile, three replicates with the same size were prepared and distributed randomly within the experimental as check.

All other agronomical practices for sugarcane crop were adapted as recommended in Qena Governorate.

\section{Irrigation systems.}

Two irrigation systems were used, the first one was drown system, while the second one was modern system, each system area represented $420 \mathrm{~m}^{2}$ was cultivated by C9/54 sugarcane variety. Divided to three replicates $70 \mathrm{~m}^{2}$ for each, all the experimental plots received the normal agricultural treatments and no chemical control measurements were applied.

\section{Plant crop and ratoon plant.}

Plant crop and four ratoons $\left(1^{\text {st }}, 2^{\text {nd }}, 3^{\text {rd }}\right.$ and $4^{\text {th }}$ ratoon $)$ were selected in an area about $1050 \mathrm{~m}^{2}$, divided to 3 replicates for each treatment. $\left(210 \mathrm{~m}^{2}\right.$ for each). All other agronomical practices for sugarcane crop were adapted as recommended..

\section{Certain sugarcane varieties}

PH 8013, F 160 and commercial variety C 9/54 were cultivated in 210 $\mathrm{m}^{2}$ for each variety. Divided into 3 replicates $\left(70 \mathrm{~m}^{2}\right.$ for each). The randomized complete block design was followed in the whole experimental area. The tested varieties were exposed to normal field condition without using insecticides during the experimental period

Fayoum J. Agric. Res. \& Dev., Vol.19, No.2, July, 2005 
EFFECT OF CERTAIN AGRICULTURAL PRACTICES ON 122

\section{Host range}

Inspection of sugarcane plant and other field crops associated with the sugarcane plant and weeds were occurred during three successive seasons started from, 15 October 2001 until late of December 2004 seasons. Forty plants for each crop or weed represented one feddan were randomly chosen, each 15 days intervals. Careful examination of these plant was done to clarify the existence of different stages of the soft scale P.tenuivalvata.

\section{RESULTS AND DISCUTION}

\section{Effect of planting spaces.}

Effect of planting space on infestation of sugarcane plants by the soft scale $P$. tenuivalvata through 2002 and 2003 seasons was shown in Tables (1 and 2). The trend in number of this pest was decreased when spacing between rows was increased. In the $1^{\text {st }}$ season the total number of individuals was increased from 2461individuals in 7 rows followed by 2736 and 2782 individuals in 9 and 11 rows, respectively. In case 200 nitrogen units per feddan which treated with Potassium fertilizer. On the other hand in the same treatment without Potassium, the space 11 rows recorded the highest number 2937 individuals followed by 9 and 7 rows which recorded 2741 and 2531 individuals, respectively. The same trend was evident in the $2^{\text {nd }}$ season (2003) but with a few number of individuals. The space 11 rows were the highest value in both cases treated and untreated with Potassium 142 and 175 individuals followed by 9 and 7 rows which recorded $139 \& 175$ individuals and $131 \& 171$ individuals, respectively. Statistical analyses of data showed that there were significant differences between the space 11 and both 7 and 9 rows for insect individuals while non significant differences between 7 and 9 rows in both test seasons.

\section{Effect of nitrogen levels.}

Data presented in Tables (1 and 2) indicated that, application of different levels of nitrogen fertilizer increased of $P$. tenuivalvata populations. The infestation was lowest in sugarcane fields which treated with 150 units of nitrogen per feddan (2200, 2441 and 2615 individuals) in 7, 9 and 11 rows, respectively and increased by treated with 200 nitrogen units to 2461, 2736 and 2782 individuals in 7,9 and 11 rows, respectively. The highest number was in case treated with 250 nitrogen units which recorded 2533, 2709 and 2749 individuals in 7,9 and 11 rows, respectively.

The same trend was done in the $2^{\text {nd }}$ season. The highest number recorded in level 250 nitrogen units (136, 132 and 151 individuals) in 7,9 and 11 rows, respectively. Followed by level 200 nitrogen units which were 131, 139 and 142 individuals respectively. While the lowest number was occurred in level 150 nitrogen units 115, 120 and 136 individuals, in 7, 9, 11 rows, respectively. Statistical analyses of these data showed that. There were significant differences in number insect individuals between 150 units of Nitrogen fertilizer and $200 \& 250$ units as well as non significant between 200 $\& 250$ units of Nitrogen fertilizer in both seasons.

Fayoum J. Agric. Res. \& Dev., Vol.19, No.2, July, 2005 
Ramadan A.K. Salama, et al.

Table 1

Fayoum J. Agric. Res. \& Dev., Vol.19, No.2, July, 2005 
EFFECT OF CERTAIN AGRICULTURAL PRACTICES ON........... 124

Table 2

Fayoum J. Agric. Res. \& Dev., Vol.19, No.2, July, 2005 
Ramadan A.K. Salama, et al.

Effect of potassium fertilizer

Effect of potassium fertilization on population density of soft scale, $P$. tenuivalvata was shown in Tables (1 and 2). The lowest infested by $P$. tenuivalvata was recorded on plant cane treated with potassium fertilization at rate of $100 \mathrm{~kg} /$ feddan. In the $1^{\text {st }}$ season. (2002) the total number of individuals were 2461, 2736 and 2782 individuals in 7, 9 and 11 rows, respectively in addition of 200 units of nitrogen per feddan compared with untreated treatment which recorded 2531, 2741 and 2937 individuals in 7, 9 and 11 rows, respectively. Whereas the total number of individuals, in the $2^{\text {nd }}$ season (2003) were recorded lower density in general than the $1^{\text {st }}$ season. The treated with Potassium were 131, 139, 142 individuals in 7,9 and 11 rows, respectively, with 200 units of nitrogen per feddan. The number of individuals increased in untreated plots which received 171, 175 and 175 individuals in 7, 9 and 11 rows, respectively. Analyses of variance of data showed significant difference between the plots which treated and untreated with Potassium fertilizer.

\section{Irrigation systems}

Effect of irrigation systems of sugarcane plants (Drown and Modern) were investigated in this work to determine the top rated of irrigation system which can reduced of population density of $P$. tenuivalvata as one of methods of sugarcane protection system .It was evident in Table (3) the population of $P$. tenuivalvata was height in Drown system in both seasons which recorded 136 and 44 individuals per 90 leaves for $1^{\text {st }}$ and $2^{\text {nd }}$ seasons, respectively compared with Modern system which recorded 108 and 38 individuals /90 leaves. Statistical analysis of data showed significant differences between Drown and Modern system in $1^{\text {st }}$ season (2002) while was non significant in the $2^{\text {nd }}$ season (2003).

Table (3): Effect of Irrigation systems in sugarcane fields on population density of $P$. tenuivalvata $/ 90$ leaves during $2002 \& 2003$ seasons.

\begin{tabular}{|c|c|c|c|c|}
\hline \multirow{2}{*}{ Date } & \multicolumn{2}{|c|}{ 2002 season } & \multicolumn{2}{c|}{ 2003 season } \\
\cline { 2 - 5 } & Modern & Drown & Modern & Drown \\
\hline $12 / 08 /$ & 0 & 3 & 0 & 0 \\
\hline $27 / 08 /$ & 3 & 15 & 0 & 0 \\
\hline $11 / 09 /$ & 20 & 15 & 3 & 3 \\
\hline $26 / 09 /$ & 20 & 15 & 15 & 22 \\
\hline $11 / 10 /$ & 22 & 19 & 16 & 15 \\
\hline $26 / 10 /$ & 26 & 36 & 4 & 4 \\
\hline $10 / 11 /$ & 17 & 33 & 0 & 0 \\
\hline Total & 108 & 136 & 38 & 44 \\
\hline Mean & 15.42 & 19.42 & 9.5 & 11 \\
\hline T. calculated & \multicolumn{3}{|c|}{$5.26^{*}$} & \multicolumn{3}{c|}{$3.48 \mathrm{~ns}$} \\
\hline
\end{tabular}

Effect of plant crop and ratoon plant.

Results presented in Table (4) showed the infestation by $P$. tenuivalvata on plant crop and ratoons plant started in August in both season. The number of $P$. tenuivalvata $/ 90$ leaves was lowest on plant crop which received 98 and 33 individuals in $1^{\text {st }}$ and $2^{\text {nd }}$ seasons, respectively, then the population increased progressively in the following ratoons which received 112, 136, 149

Fayoum J. Agric. Res. \& Dev., Vol.19, No.2, July, 2005 
EFFECT OF CERTAIN AGRICULTURAL PRACTICES ON.......... 126

Table 4

Fayoum J. Agric. Res. \& Dev., Vol.19, No.2, July, 2005 
Ramadan A.K. Salama, et al.

and 209 individuals in $1^{\text {st }}, 2^{\text {nd }}, 3^{\text {rd }}$ and $4^{\text {th }}$ ratoons, respectively in the $1^{\text {st }}$ season, while in the $2^{\text {nd }}$ season the population of $P$. tenuivalvata was 37, 41, 44 and 47 in $1^{\text {st }}, 2^{\text {nd }}, 3^{\text {rd }}$ and $4^{\text {th }}$ ratoons, respectively. Statistical analysis of the date appeared that in the $1^{\text {st }}$ season the data showed different significant in number of individuals between the plant crop and other ratoons also there were significant between the $1^{\text {st }}$ ratoon, $3^{\text {rd }}$ and $4^{\text {th }}$ ratoons. Moreover there were significant differences between 2 nd and $4^{\text {th }}$ ratoons while did not significant differences between $2^{\text {nd }}$ and $4^{\text {th }}$ ratoons. In the $2^{\text {nd }}$ season the data showed different significant between the plant crop and $3^{\text {rd }} \& 4^{\text {th }}$ ratoons also between $1^{\text {st }}$ ratoon and the $4^{\text {th }}$ ratoon. While non significant differences between plant crop and $1^{\text {st }} \& 2^{\text {nd }}$ ratoon also between $1^{\text {st }}, 2^{\text {nd }}$ and $3^{\text {rd }}$ ratoons.

\section{Susceptibility of certain sugarcane varieties to soft scale insect $P$. tenuivalvata infestation}

As shown in Table (5) the data indicated that C 9/54 sugarcane variety was the most susceptible to $P$. tenuivalvata infestation in both seasons (2003 and 2004) with 161 and 109 individuals /90 leaves, respectively. Followed by F160 variety which received 84 and 55 individuals /90 leaves. While PH 8013 variety was the least susceptible to insect infestation which received 62 and 46 individuals per 90 leaves during (2003 and 2004) seasons, respectively. Statistical analysis of this data showed significant differences between three sugarcane varieties through two seasons.

Table (5): Effect of certain sugarcane varieties on the population density of P.tenuevalvata / 90 leaves during 2003 and 2004 seasons.

\begin{tabular}{|c|c|c|c|c|c|c|}
\hline \multirow[b]{2}{*}{ Date } & \multicolumn{3}{|c|}{2003 season } & \multicolumn{3}{|c|}{2004 season } \\
\hline & C9/54 & PH8013 & F160 & C9/54 & PH8013 & F160 \\
\hline $13 / 07 /$ & 5 & 0 & 0 & 0 & 0 & 0 \\
\hline $28 / 07 /$ & 7 & 0 & 1 & 5 & 1 & 1 \\
\hline $12 / 08 /$ & 8 & 2 & 3 & 14 & 3 & 3 \\
\hline $27 / 08 /$ & 13 & 5 & 8 & 15 & 6 & 4 \\
\hline $11 / 09 /$ & 18 & 7 & 9 & 18 & 7 & 15 \\
\hline $26 / 09 /$ & 20 & 8 & 10 & 25 & 9 & 12 \\
\hline $11 / 10 /$ & 23 & 15 & 15 & 17 & 13 & 10 \\
\hline $26 / 10 /$ & 45 & 18 & 28 & 10 & 5 & 7 \\
\hline 10/11/ & 17 & 5 & 9 & 5 & 2 & 3 \\
\hline $25 / 11 /$ & 5 & 2 & 1 & 0 & 0 & 0 \\
\hline Total & 161 & 62 & 84 & 109 & 46 & 55 \\
\hline Mean & $16.1 \mathrm{a}$ & $6.2 \mathrm{c}$ & $8.4 \mathrm{~b}$ & $12.11 \mathrm{a}$ & $5.11 \mathrm{c}$ & $6.11 \mathrm{~b}$ \\
\hline F-value & \multicolumn{3}{|c|}{$426.68^{*}$} & \multicolumn{3}{|c|}{$387 *$} \\
\hline LSD at level 0.05 & \multicolumn{3}{|c|}{3.29} & \multicolumn{3}{|c|}{2.27} \\
\hline
\end{tabular}

\section{Host range}

Host range of sugarcane soft scale, $P$. tenuivalvata was conducted on sugarcane field and other plant which existent in or surround sugarcane fields throughout three successive seasons from 2002 to 2004 seasons. The data showed in Table (6) indicated that ten host plants were belonged to family Graminaceae. They were as follows; 4 field crop plant (maize, sorghum, sugarcane and wheat) and 6 weed (Conogn grass, Common reed, Elephant grass, Green foxtail, Eerennial ryegrass and Large crabgrass). All soft scale insect stages were recorded on 5 plant species (Conogn grass, Maize,

Fayoum J. Agric. Res. \& Dev., Vol.19, No.2, July, 2005 
EFFECT OF CERTAIN AGRICULTURAL PRACTICES ON

Sorghum, sugarcane and wheat). While observed three nymphs instars on 3 plant species (Common reed, Elephant grass and Green foxtail). Moreover received Eerennial ryegrass and Large crabgrass the $1^{\text {st }}$ and $2^{\text {nd }}$ nymphl instars only. On the other hand frequency of $P$. tenuivalvata individuals were highly abundant on sugarcane and Conogn grass plant and abundant on Common reed, Eerennial ryegrass and Large crabgrass. while were rared on maize, sorghum, wheat, Elephant grass and Green foxtail.

Results obtained in this study agreed with those recorded by different authors. Shalaby (2002) showed that a negative correlation and relationship was found between row spacing and population density of scale, Pulvinaria tenuivalvata, so the number of scale per leaf significantly decreased as the space between rows increased.

Beckham (1970) noticed there was an indication that more aphids occurred on leaves as the rate of nitrogen was increased. On the contrary Washburn et al., (1987) reported no significant correlation was found between the amount or form of nitrogen addition and survivorship of Pulvinaria delotto, and Rae \& Jones (1992) found that nitrogen did not have a detectable effect on the population size of Saccharicoccus sacchari on sugarcane. Shalaby (2002) observed that application of potassium with nitrogen decreased in the density of Pulvinaria tenuivalvata infesting sugarcane leaves.

Maareg et al., (1992) showed that the ratoon cane were the worst affected by scale insect infestation. The same meaning cleared Ravindranath and Subbaratnam (1998) that ratoon crops had a higher level of infestation than plant crops, while Besheit et al., (2002) reported that the severe infestation of soft scale, Pulvinaria tenuivalvata on the first and second ratoon was less effect on most juice quality and the average stalk weight, reducing sugar and glucose ratio of plant cane were less effective under heavy infestation compared with ratoon crop.

Parsana et al., (1994) observed that the highest population levels of Saccharicoccus sacchari were recorded in the traditional flood method of irrigation.

Table (6): Host range of the strip soft scale, P.tenuivalvata existent in or surround sugarcane fields in Nagada region during three successive seasons from 2002 to 2004.

\begin{tabular}{|l|c|l|c|c|}
\hline Common name & \multicolumn{1}{|c|}{ Scientific name } & Family & Frequency & insect stage \\
\hline Maize & Zea mays L. & Graminaceae & A & all stages \\
\hline Sorghum & Sorghum bicolor L. & Graminaceae & A & all stages \\
\hline Sugarcane & Saccharum officinarum L. & Graminaceae & Ha & all stages \\
\hline Wheat & Triticum aestivum L. & Graminaceae & A & all stages \\
\hline Conogn grass & Imperata cylindrica L. & Graminaceae & Ha & all stages \\
\hline Common reed & Phragmites australis Trin. & Graminaceae & R & II ,III nymphs \\
\hline Elephant grass & Pennisetum purpureum Schu. & Graminaceae & A & II ,III nymphs \\
\hline Green foxtail & Setaria viridis (L.) & Graminaceae & A & II ,III nymphs \\
\hline Eerennial ryegrass & Lolium perenne L. & Graminaceae & R & II nymph \\
\hline Large crabgrass & Lolium perenne L. & Graminaceae & R & II nymph \\
\hline \multicolumn{1}{|c|}{ Common name } & Digiaria sanguinalis (L.) & Graminaceae & R & II nymph \\
\hline
\end{tabular}

Ha : Highly abundant A : abundant $\quad$ R : Rare

Fayoum J. Agric. Res. \& Dev., Vol.19, No.2, July, 2005 
REFERENCES

Ali, M. A. M.; A. S. El-Khouly; F. El-Metwally, and M. I. S. Shalaby (2000): Occurrenc,distribution and host range of the sugarcane soft scale, Pulvinaria tenuivalvata (Newstead) in upper Egypt. Bull. Ent. Soc. Egypt, 78:243-250.

Beckham, C.M. (1970): Effect of nitrogen fertilization on the abundance of cotton insect. J. Econ. Ent. 63 (4): 1219-1224.

Besheit, S. Y.; A.A. Abaziad; A.M. El-Gomaa; A. S. Abo El-Hamd (2002): The influence of the infestation by the soft scale insect, Pulvinaria tenuivalvata (Newstead), Coccidae Homoptera on sugarcane stalk weight, juice quality and sugar yield in Upper Egypt Assut J. of Agric. Sci. 33 (4): 17-28.

Campos, M.S. (1997): Pulvinaria spp. On sugarcane under insectary conditions. Cited R.A.E. Ser. A .85 (5): 624.

Maareg, M. F.; M. A. Hassanein and A. M. Abu Dooh (1992): Preliminary survey of the scale insects attacking sugarcane in Egypt. Com. in Sci. \& Dev. Res. 498 : 223-230.

Moholkar, P. R.; S.T. Ranaive and O.V. Jawalekar (1973): Effect of scale insect, Melanaspis golmerata G. of sugarcane on the quality and recovery of jaggery (gur). Proc. Conr. Deccan. Sug. Technol. Assoc., 25: 41-44.

Parsana, G.J; D.D. Malavia and D.J. Koshiya (1994): Effect of drip irrigation on incidence of insect pests of sugarcane. Gujarat, Agric. Uni. Res. J. 20 (1): 15-17.

Rae, D.J. and R.E. Jones (1992): Influence of host nitrogen levels on development, survival, size and population dynamics of sugarcane mealybug, Saccharicoccus sacchari (Cockerell) (Hemiptera: Pseudococcidae). Australian Journal of Zoology 40 (3): 327-342.

Raghunath, T. (1983): Leaf nitrogen as a possible factor in resistance of sugarcane varieties to the scale insect Melanaspis glomerata G. Maharashtra Sugar 8 (11): 69-71.

Ravindranath, K. and G.V. Subbaratnam (1998): Relative susceptibility of some varieties of sugarcane to the scale insect, Melanaspis glomerata. Pest Management and Economic Zoology. 6 (2): 159-161.

Shalaby, M.S.I. (2002): Ecological and biological studies on the sugarcane scale Pulvinaria tenuivalvata (Newstead) infesting sugarcane in Giza Governorate. Ph.D. Sci. Thesis, Fac. of Agric., Al-Azhar Univ.,Cairo, Egypt. 209 pp.

Washburn, J.O.; J.K. Grace and G.W. Frankie (1987): population responses of Pulvinariella mesembryanthemi and Pulvinaria delottoi (Homoptera: Coccidae) to nitrogen and water conditions of their host plant. Environ. Entomol. 16 (1): 286-295.

Watson, J.W. and I. Foldi (2001): The identify of red -striped soft scale, on sugarcane in Egypt, Pulvinaria tenuivalvata (Newstead) (Homoptera : coccidae) Bull. Ent. Soc. Egypt, 79:

Williams, J.R. (1970): Studies on the biology, ecology and economic importance of the sugarcane scale insect, Aulacaspis tegalensis (Zhnt.) (Diaspididae) in Nauritius. Bull. Ent. Res.60: 61-95.

Fayoum J. Agric. Res. \& Dev., Vol.19, No.2, July, 2005 
تأثير بعض الممارسات الزراعية على الكثافة العددية لحشرة القصب

\section{Pulvinaria tenuivalvata القشرية الرخوارئ}







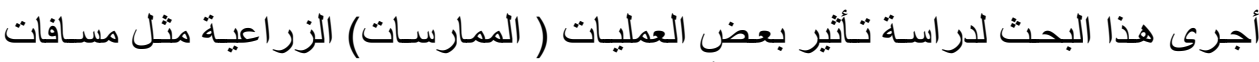



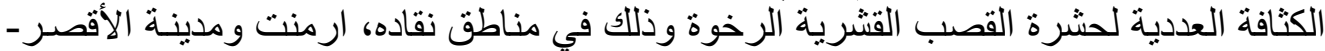

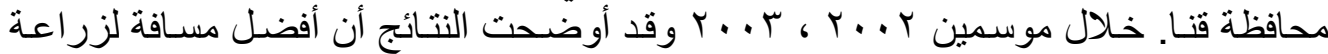

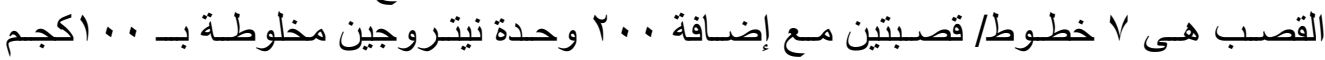
بوتاسيوم للفدان تحت نظام الري المطور مـع استخدام صنف القصب

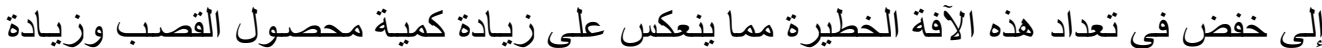

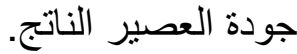

Fayoum J. Agric. Res. \& Dev., Vol.19, No.2, July, 2005 